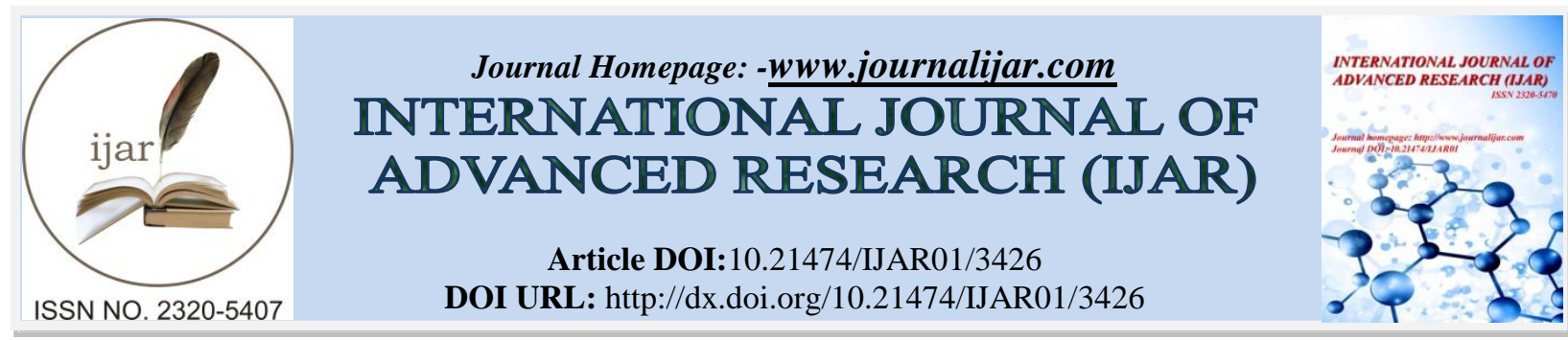

RESEARCH ARTICLE

\title{
CHARACTERISTICS AND USES OF ZEOLITES AND CLAYS AS CATALYTIC SUPPORTS. A REVIEW.
}

Maria M. Guerra-Nunez*, J. Herney Ramirez and Luis A. Santis.

Department of Chemical and Environmental Engineering, Faculty of Engineering, National University of Colombia, Carrera 30 Number 45-03, Bogota D.C, Colombia.

\section{Manuscript Info}

Manuscript History

Received: 11 December 2016

Final Accepted: 16 January 2017

Published: February 2017

Key words:-

supports, zeolites, clays, synthesis,

heterogeneous catalysts

\section{Abstract}

The economic significance of catalysis is enormous because most industrial chemical processes are catalytic. The use of heterogeneous catalysts and their importance have grown in recent years as a result of the economic and environmental benefits it has, compared to homogeneous catalysts. In that sense, a study deals with the use of catalytic supports on which active phases are deposited, is also developed. This review focuses on the most widely used catalytic supports, zeolite and clays. Among the topics discussed in this report are characteristics, types, synthesis and applications of the catalyst support referred above.

Copy Right, IJAR, 2017,. All rights reserved.

\section{Introduction:-}

During last years, environmental organizations and some sectors society have claimed for a strict control over effluents generated in processes like oil extraction or use of dyes, which may pollute the environment. Therefore, efforts are being made to perform the replacement of the classical stoichiometric processes with homogeneous basic catalysts, such as sodium hydroxide, potassium ethoxide, by processes with heterogeneous basic catalysts to decrease generation of these contaminants and increasing economic and environmental benefits (Martín, 2001). Among materials that can be used as catalyst, zeolites and clays are the most widely used as their porous structure has interesting properties to be used in catalysis, ion exchange and adsorption. However, another materials, natural or synthetic, have also been used through the years as catalyst support in the catalyst.

The support performs many functions, but the most important one is the maintenance of high surface area for the active component. Support functions as stable surface over which the active component is dispersed in such way that sintering is reduced. To work as a catalyst, the support must resist higher temperatures, than the active component, which means a higher melting point, and must be easily manipulated to produce optimum texture properties. The most direct effect of the support on the catalyst is related to dispersion and morphology (Mirzaei, Vahid, \& Torshizi, 2013). For applications, these materials have been characterized by X-ray diffraction analysis (XRD), Fouriertransfo infrared spectroscopy (FTIR), scanning electron microscopy (SEM), energy-dispersive X-ray spectroscopy $($ EDX), reflectance, and cation exchange capacity analysis (CEC) and other techniques.

The main objective of this review is to present two materials commonly used as catalyst supports, their characteristics, sources, synthesis and industrial and environmental applications as catalytic supports. Zeolite and clay supports are widely used due to their properties such as high surface area, thermal stability, strong acidity and presence of nanosized spaces within their pores.

CorrespondingAuthor:- Maria M. Guerra-Nunez.

Address:- Department of Chemical and Environmental Engineering, Faculty of Engineering, National 


\section{Zeolite:- \\ Introduction:-}

Zeolites consist of interconnected aluminosilicate building blocks of $\mathrm{AlO}_{4}$ and $\mathrm{SiO}_{4}$ tetrahedral units, which form three-dimensional framework with linked channel systems and well definedmicropores. Because of their high degree of open pores and microporous nature, these materials possess very high surface area (Kim, Rajesh, \& Yu, 2013) and is possible find more than 170 different zeolite crystal structures and their crystallographic data from the database of the International Zeolite Association (IZA). Natural zeolites were discovered around 1756 by geologist A. Cronstedt when he observed that certain minerals when heated, melted and boiled at the same time, then called them Zeolites (Greek for "zeo" boil and lithos stone) (Martín, 2001).Generally, the following chemical formula is used to represent zeolites,

$\mathrm{A}_{\mathrm{y} / \mathrm{m}}^{\mathrm{m}+}\left[\left(\mathrm{SiO}_{2}\right)_{\mathrm{x}}\left(\mathrm{AlO}^{-2}\right)_{\mathrm{y}}\right] \mathrm{zH}_{2} \mathrm{O}$

where A is charge-balancing cation with valance $\mathrm{m},(\mathrm{x}+\mathrm{y})$ is the number of tetrahedral units per crystallographic unit cell, $\mathrm{x} / \mathrm{y}$ is the ratio of silicon to aluminum and $\mathrm{z}$ is the number of water molecules associated with the zeolite unit cell. The ratio $\mathrm{x} / \mathrm{y}$ usually varies from 1 to 5 although pure silica form of zeolite is also available with $\mathrm{x} / \mathrm{y}$ being infinite (Kim et al., 2013).

Zeolites are the catalyst supports more employees and their industrial applications are due to their physicochemical properties, which have favored the use in many industrial processes such as adsorption, ion exchange and molecular sieving (Musyoka, Missengue, Kusisakana, \& Petrik, 2014). Mainly have been studied acidic zeolites for their industrial importance, but environmental advantages offered by basic zeolites, such as replacing processes that generate large amounts of contaminants, makes their study is in development (Martín, 2001).

\section{Zeolite synthesis:-}

The first synthetic zeolite was produced in 1950 by Union Carbide Linde Corporation in United States to be used as ion exchangers, and then increase their use as catalysts, adsorbents or detergents. Synthetic zeolites have been taked an unprecedented growth, to the extent that today various patents related to the synthesis of these materials are known (Rios, Williams, \& Castellanos, 2006). Zeolites are typically synthesized under hydrothermal conditions from alkaline aqueous solutions. A typical hydrothermal zeolite synthesis can be described in briefest terms as follows: 1. amorphous reactants containing silica and alumina are mixed together with a cation source, usually in a basic medium; 2. the aqueous reaction mixture is heated (for reaction temperatures above $100^{\circ} \mathrm{C}$ ), often in a sealed autoclave; 3. For a period at synthesis temperature, the reactants remain amorphous; 4. After the above "induction period", the crystalline zeolite products are formed; 5. Gradually, most amorphous materials are replaced by an approximately equal mass of the zeolite crystals (Cundy \& Cox, 2005). Most used silicon sources are aqueous colloidal silica (Zhang, Tang, Zhang, \& Yang, 2013), silica foam (Nabavi, Mohammadi, \& Kazemimoghadam, 2014), sodium silicate, tetraethyl orthosilicate(Zhang, Tang, \& Jiang, 2013), and a mixture of them (Zhang, Tang, \& Jiang, 2013). Sodium aluminate (Mousavi, Jafari, Kazemimoghadam, \& Mohammadi, 2013; Nabavi et al., 2014; Zhang, Tang, Zhang, et al., 2013) or a mixture of sodium aluminate, aluminum sulfate, alumina, aluminum hydroxide and aluminum isopropoxide(Zhang, Tang, \& Jiang, 2013) are the alumina sources. Cation source, usually is sodium hydroxide (Nabavi et al., 2014; Zhang, Tang, \& Jiang, 2013; Zhang, Tang, Zhang, et al., 2013).

Typical hydrothermal synthesis using chemicals isdescribed above and times and conditions for each case vary according to the type of zeolite to be obtained. However, the high cost and limited availability associated to these chemicals have promoted the search for alternative low cost raw materials. Some of the alternative unconventional feedstocks are coal fly ash, rice husks, natural clay minerals and bagasse, among other feedstocks. The type and source of silica and alumina feedstock strongly influence the quality and the purity of the final zeolite product (Musyoka et al., 2014).

\section{Synthesis of different types of zeolites:-}

Synthesis of zeolites from clays obtained from South Africa has been investigated. The conventional alkaline hydrothermal treatment of the starting material $\left(90^{\circ} \mathrm{C}\right.$ for $\left.8 \mathrm{~h}\right)$ was preceded by a fusion step $\left(550{ }^{\circ} \mathrm{C}\right.$ for $\left.1.5 \mathrm{~h}\right)$ to improve the solubility of aluminium and silicon. X-ray diffraction patterns showed that a mixture of hydroxysodalite zeolite and zeolite $\mathrm{X}$ was formed when starting from bentonite and red clay, whereas the main zeolitic product formed from white clays was hydroxysodalite zeolite. Upon addition of extra Al to the synthesis mixture, zeolite $\mathrm{X}$ 
was found to be the main zeolitic material that was formed after the hydrothermal crystallization. A well definedmorphology for the formed zeolite $\mathrm{X}$ was observed when starting from red clay synthesis feedstock (Musyoka et al., 2014).

In another study, mine waters obtained from coal mining operations in South Africa were used as a substitute for pure water during the synthesis of Na-P1 and X zeolites from coal fly ash (Musyoka, Petrik, Fatoba, \& Hums, 2013). Whencircumneutral mine waterwas used for Na-P1 synthesis, extra cations did not have any profound effect in the crystallization of this specific zeolite. For zeolite $\mathrm{X}$ case, a mixture of hydroxysodalite and zeolite $\mathrm{X}$ was obtained, which was unlike. Use of the acid mine water, for Na-P1 synthesis only a single phase hydroxysodalite zeolite could be obtained, whereas for $\mathrm{X}$ zeolite synthesis had the formation of hydroxysodalite zeolite with trace amounts of zeolite X. Both zeolites, Na-P1 and X zeolite have applications in water treatment.

Moreover, a variety of organic compounds have been degraded over iron or copper exchanged zeolites. Fenton like processes have been used in the catalytic treatment of phenol, azo dye and others, such as is shown in Table 1 (Garrido-Ramírez, Theng, \& Mora, 2010).

Table 1:- Catalytic degradation of organic compounds over iron or copper exchanged zeolites through different Fenton-like processes (Garrido-Ramírez et al., 2010).

\begin{tabular}{|c|c|c|c|}
\hline Compound & Catalyst/support & Process & Reference \\
\hline $\begin{array}{l}\text { Remazol Brilliant Orange } \\
\text { 3C }\end{array}$ & $\begin{array}{l}\text { Fe(III)-exchanged natural } \\
\text { zeolite }\end{array}$ & Photo-Fenton & Tekbas et al. (2008) \\
\hline $\begin{array}{l}\text { Indigoid dye C.I. Acid } \\
\text { Blue } 74\end{array}$ & $\begin{array}{l}\text { Fe-ZSM-5 synthetic } \\
\text { zeolite }\end{array}$ & Photo-Fenton & Kasiri et al. (2008) \\
\hline $\begin{array}{l}\text { Reactive } \\
\text { KN-R }\end{array}$ & $\mathrm{Fe}-\mathrm{NaY}$ and $\mathrm{Fe}-\mathrm{ZSM}-5$ & Fenton-like reaction & Chen et al. (2008) \\
\hline Azo dye Acid Violet 7 & $\begin{array}{l}\mathrm{Fe}(\mathrm{III}) \text { immobilized } \mathrm{Al}_{2} \mathrm{O}_{3} \\
\text { catalyst }\end{array}$ & Photo-Fenton & $\begin{array}{ll}\text { Muthuvel } & \text { and } \\
\text { Swaminathan (2008) } & \end{array}$ \\
\hline $\begin{array}{l}\text { Azo dye Porción Marine } \\
\text { H-EXL }\end{array}$ & Fe-exchanged Y zeolite & $\begin{array}{l}\text { Wet hydrogen peroxide } \\
\text { oxidation }\end{array}$ & Neamtu et al. (2004b) \\
\hline Acid Brown & $\begin{array}{l}\text { Mn-exchanged } \quad \mathrm{Na}-\mathrm{Y} \\
\text { zeolite }\end{array}$ & $\begin{array}{l}\text { Wet hydrogen peroxide } \\
\text { oxidation }\end{array}$ & Aravindhan et al. (2006) \\
\hline $\begin{array}{l}\text { C.I. Reactive Yellow } 84 \\
\text { (RY84) }\end{array}$ & Fe-Y zeolite & $\begin{array}{l}\text { Wet hydrogen peroxide } \\
\text { oxidation }\end{array}$ & Neamtu et al. (2004a) \\
\hline Phenol & $\mathrm{Cu}-\mathrm{Y}-5$ & $\begin{array}{l}\text { Wet hydrogen peroxide } \\
\text { oxidation }\end{array}$ & $\begin{array}{l}\text { Zrnčević and Gomzi } \\
(2005)\end{array}$ \\
\hline \multirow[t]{2}{*}{ Chlorinated phenols } & Fe-Beta zeolite & Fenton-like reaction & Doocey et al. (2004) \\
\hline & Fe-4A zeolite & & \\
\hline Phenolic solutions & $\begin{array}{l}\text { Fe-NaY,Fe-USY and Fe- } \\
\text { ZSM-5 }\end{array}$ & Fenton-like reaction & Ovejero et al. (2001b) \\
\hline Phenol & Fe(III)-HY catalyst & Photo-Fenton & Noorjahan et al. (2005) \\
\hline Phenol & MFI zeolite & $\begin{array}{l}\text { Wet hydrogen peroxide } \\
\text { oxidation }\end{array}$ & Ovejero et al. (2001a) \\
\hline Phenol & $\mathrm{Cu}-\mathrm{ZSM}-5$ & $\begin{array}{l}\text { Wet hydrogen peroxide } \\
\text { oxidation }\end{array}$ & Valkaj et al. (2007) \\
\hline $\begin{array}{l}\text { 1,1-Dimethylhydrazine and } \\
\text { ethanol }\end{array}$ & Fe-MF1 zeolite catalyst & Fenton-like reaction & Kuznestsova et al. (2008) \\
\hline 1,1-Dimethylhydrazine & Fe-ZSM-5 zeolite & Fenton-like reaction & Makhotkina et al. (2006) \\
\hline Carboxylic acids & Fe-ZSM-5 & $\begin{array}{l}\text { Wet hydrogen peroxide } \\
\text { oxidation }\end{array}$ & Centi et al. (2000) \\
\hline Acetic acid & $\mathrm{Cu}-\mathrm{NaY}$ zeolite & $\begin{array}{l}\text { Wet hydrogen peroxide } \\
\text { oxidation }\end{array}$ & Larachi et al. (1998) \\
\hline 2,4-xylidine & Fe(III)-zeolite Y & Fenton-like reaction & Rios-Enriquez et al. (2004) \\
\hline
\end{tabular}




\section{Novel Support applications:-}

Different zeolite nanocrystalsas ZSM-5, Beta polymorph A (BEA) and Faujasite (FAU) were used as solid supports for the preparation of $\mathrm{Ag}$ nanoparticles with different morphologies. Silver nanoparticles supported on zeolite crystals are considered for enhancing the efficiency of hybrid photovoltaic solar cells due to their plasmonic properties, besides Ag nanoparticles could induce light scattering and increase the number of photons entering the cell. The problem of hole-electron recombination or loss of excitation in classical solar cells can be solved with the fabrication of very thin photovoltaic solar cells (few hundreds of micrometers) using Ag nanoparticles on zeolites. Incorporation of silver in zeolites has antimicrobial and medical applications because when moisture or liquid film gets in contact with Ag-zeolite, silver ions are released to the bacteria by forming chelate complexes with the DNA and block the transport processes in the cell.

Also, zeolites have been functionalized with molecular targeting vectors that enable specific high affinity binding to in vivo molecular targets (such as cell surface receptors). In addition, these materials possess unique properties that enable radionuclides and contrast agent metals to be concentrated for applications in magnetic resonance imaging (MRI) and positron emission tomography (PET) (Zaarour, Dong, Naydenova, Retoux, \& Mintova, 2014).

\section{Mineral Clays:- Introduction:-}

Clay is hydrated aluminosilicate whose chemical formula is $\mathrm{Al}_{2} \mathrm{O}_{3} \cdot 2 \mathrm{SiO}_{2} \cdot 2 \mathrm{H}_{2} \mathrm{O}$. Its chemical composition is characterized by the presence of amounts of $\mathrm{Mg}, \mathrm{Mn}, \mathrm{Fe}, \mathrm{Ca}, \mathrm{Na}$ and $\mathrm{K}$, mainly. Clays belong to a particular class of minerals known phyllosilicates or sheet silicates. Silicates are, from a practical point of view, the set of most important minerals of nature as they constitute $25 \%$ of the known minerals and about $40 \%$ of the most common.

Phyllosilicates are a large family of minerals that commonly show layered structures and include kaolin, smectite, chlorite, mica and serpentine groups. Based on their layered structure, clay minerals can be categorized as types 1:1 or 2:1. Each layer forming a clay mineral particle is fundamentally built of one or two tetrahedral silicate (SilO) sheets and one octahedral metal oxide/hydroxide $(\mathrm{M} \backslash \mathrm{O}$ or $\mathrm{M} \backslash \mathrm{OH})$ sheet. A 1:1-type clay mineral consists of one tetrahedral sheet and one octahedral sheet.

Examples of 1:1-type clay are kaolinite, halloysite and serpentine. A 2:1-type clay mineral is composed of an octahedral sheet between two tetrahedral silicate $(\mathrm{Si} \backslash \mathrm{O})$ sheets, and examples of 2:1-type clay minerals include vermiculite montmorillonite, saponite, and sepiolite(Zhou \& Keeling, 2013).

\section{Active sites:-}

Some properties of the clay minerals such as the exchange capacity, good catalytic support, large surface area, mechanical and chemical stability and low price, make them suitable as heterogeneous catalysts. At this respect, clay minerals such as, montmorillonites, iron-enriched zeolites, kaolinite, allophanes, goethite, magnetite and wustite, have been used as solid catalysts in the heterogeneous Fenton and electro Fenton reactions or to prepare modified electrodes (Garrido-Ramírez, Mora, Marco, \& Ureta-Zañartu, 2013). The inherent properties of clay minerals also make them chemically active and adsorptive, thereby leading to a variety of uses as absorbent and catalyst products.

In clay minerals, the active sites may arise from 1. "Broken edge" sites and exposed surface of aluminol and silanol groups, 2. Isomorphic substitutions, 3. Exchangeable cations, 4. Hydrophobic silanol surfaces, 5. Hydration shell of exchangeable cations, and 6. Hydrophobic sites adsorbed onorganic molecules (Figure. 1). These peculiar chemical features combined with the nanometer scale layering and the interlayer spacing, allows for a variety of functional materials with potential applications in advanced technologies, in particular, nanotechnology (Zhou \& Keeling, 2013). 


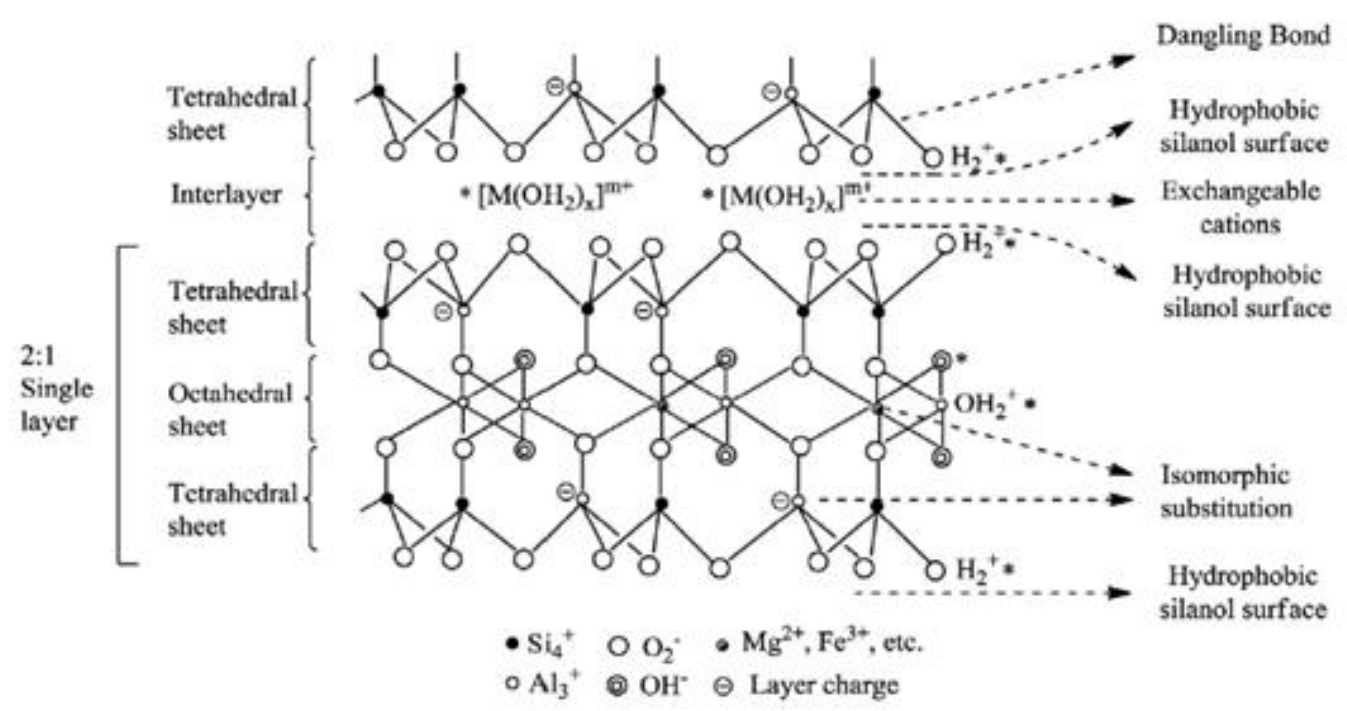

Figure 1:- Schematic drawing of 2:1- type clay mineral showing active sites (Zhou \& Keeling, 2013).

Considering the development of the clay minerals as catalysts, their chemical functions generally need to be intensified to improve efficiency. Possible ways of making 'catalytically active sites' within and onto the matrix of clay minerals are with active species in the framework of clay minerals, which can be made accessible; through the ions within the interlayer space, judiciously exchanged with active components for catalysis purpose; with functional nanoparticles (NPs) or clusters onto or within the clay nanostructure (Zhou \& Keeling, 2013).

\section{Clay mineral modification:-}

For several decades, modified clay minerals have been an important alternative for the generation of materials with potential applications in catalysis, either as catalysts or catalyst supports, due to their low cost and abundance. Their physicochemical and mechanical properties allow a very wide range of possibilities for structural, textural and chemical modifications. There aretwo methods for modifying a clay mineral,pillaring and delamination (Pérez, Montes, Molina, \& Moreno, 2014).

The Pillared InterLayered Clays (PILCs) synthesis procedure can be divided into three main steps (Ramirez et al., 2007): (i) Preparation of polyoxocations by careful hydrolysis of certain multivalent cations, which under appropriate conditions give rise to cationic polymeric species; (ii) Ionic exchange of the original chargecompensating cations of swellablesmectite clays by the polyoxocations before synthesized, this exchange giving rise to the so called "intercalated clays" and (iii) Stabilisation of the intercalated clays by calcination at relatively high temperatures, which transform the metastable polyoxocations into "pillars", stable metallic clusters, close to oxihydroxidic phases. The most widely used pillaring agent is aluminum, however, there are different poly-oxohydroxy metal cations can be used as pillaring agents like chromium, titanium and iron (Park, Jung, Seo, \& Kwon, 2009).

The process of clay mineral modification can lead to arrangements of the laminar face-face type as in the case of pillared clays, where microporosity is predominant, or edge-type or edge-side edge aggregates, as in the case of delaminated clays, which are predominantly meso and macroporous materials (Pérez et al., 2014).

PILCs, intercalared with $\mathrm{Al}$ and containing iron or copper species (Garrido-Ramírez et al., 2013; Nogueira et al., 2011; Ramirez et al., 2007; Sanabria, Álvarez, Molina, \& Moreno, 2008), have been used for the oxidative degradation of organic compounds through the Fenton-like reaction. Catalyst with intercalation of metal (Fe-AlPILC) have higher basal spacing than for their Fe-PILC counterparts (Li, Lu, \& Zhu, 2006).In Table 2 are showed catalysts for the degradation of recalcitrant organic compounds via Fenton-like reactions. 
Table 2:- PILCs as heterogeneous catalysts for the decomposition of various organic compounds via Fenton-like reactions (Garrido-Ramírez et al., 2010).

\begin{tabular}{|c|c|c|c|c|}
\hline Compound & Catalyst/support & Clay & Process & Reference \\
\hline Azo dye X-3B & Fe-PILC & Bentonite & Photo-Fenton & $\begin{array}{l}\mathrm{Li} \text { et al. } \\
(2006)\end{array}$ \\
\hline \multicolumn{5}{|l|}{ Al-Fe-PILC } \\
\hline Methylene blue & Fe-PILC & $\begin{array}{l}\text { Natural } \\
\text { montmorillonite }\end{array}$ & Photo-Fenton & $\begin{array}{l}\text { De León et al. } \\
(2008)\end{array}$ \\
\hline Orange II & Hydroxyl-Fe-PILC & Bentonite & Photo-Fenton & $\begin{array}{l}\text { Chen and Zhu } \\
(2006)\end{array}$ \\
\hline Acid Light Yellow G & Fe-PILC (catalyst) & Natural bentonite & Photo-Fenton & $\begin{array}{l}\text { Chen and Zhu } \\
(2007)\end{array}$ \\
\hline $\begin{array}{l}\text { Azo dye Orange II } \\
\text { solution }\end{array}$ & $\begin{array}{l}\text { Al-PILC impregnated } \\
\text { with Fe }\end{array}$ & Natural saponite & $\begin{array}{l}\text { Fenton-like } \\
\text { reaction }\end{array}$ & $\begin{array}{l}\text { Ramírez et al. } \\
(2007 a)\end{array}$ \\
\hline $\begin{array}{l}\text { Ciprofloxacin } \\
\text { (fluoroquinolones) }\end{array}$ & Fe-PILC & $\begin{array}{l}\text { Laponite (synthetic } \\
\text { hectorite) }\end{array}$ & Photo-Fenton & $\begin{array}{l}\text { Bobu et al. } \\
(2008)\end{array}$ \\
\hline Phenol & Mixed (Al-Fe)-PILC & $\begin{array}{l}\text { Commercial Greek } \\
\text { bentonite }\end{array}$ & $\begin{array}{lr}\text { Catalytic } & \text { wet } \\
\text { oxidation } & \text { with } \\
\mathrm{H}_{2} \mathrm{O}_{2} & \\
\end{array}$ & $\begin{array}{l}\text { Barrault et al. } \\
(2000 a)\end{array}$ \\
\hline Phenol & $\mathrm{Al}-\mathrm{Cu}-\mathrm{PILC}$ & $\begin{array}{l}\text { Commercial Greek } \\
\text { bentonite }\end{array}$ & $\begin{array}{lr}\text { Catalytic } & \text { wet } \\
\text { oxidation } & \text { with } \\
\mathrm{H}_{2} \mathrm{O}_{2} & \\
\end{array}$ & $\begin{array}{l}\text { Barrault et al. } \\
(2000 \mathrm{~b})\end{array}$ \\
\hline 4-Nitrophenol & Fe(III)-exchanged PILC & Montmorillonite & $\begin{array}{l}\text { Fenton-like } \\
\text { reaction }\end{array}$ & $\begin{array}{l}\text { Chirchi and } \\
\text { Ghorbel } \\
\text { (2002) }\end{array}$ \\
\hline Phenol & $\begin{array}{l}\text { Al-Al-Fe- and Al-Ce-Fe- } \\
\text { PILC }\end{array}$ & $\begin{array}{l}\text { Natural Colombian } \\
\text { bentonite }\end{array}$ & \begin{tabular}{|lr} 
Catalytic & wet \\
oxidation & with \\
$\mathrm{H}_{2} \mathrm{O}_{2}$ & \\
\end{tabular} & $\begin{array}{l}\text { Carriazo et al. } \\
(2005 \mathrm{a})\end{array}$ \\
\hline Benzene & $\begin{array}{l}\mathrm{Al} \text {-PILC as supports for } \\
\mathrm{Cu}, \mathrm{V}, \mathrm{Fe}\end{array}$ & $\begin{array}{l}\text { Natural sodium } \\
\text { montmorillonite }\end{array}$ & $\begin{array}{l}\text { Fenton-like } \\
\text { reaction }\end{array}$ & $\begin{array}{l}\text { Pan et al. } \\
(2008)\end{array}$ \\
\hline $\begin{array}{l}\text { p-Coumaric acid and p- } \\
\text { hydroxybenzoic acid olive } \\
\text { oil mill wastewater }\end{array}$ & $\mathrm{Cu}-\mathrm{PILC}$ & $\begin{array}{l}\text { Commercial } \\
\text { bentonite }\end{array}$ & $\begin{array}{l}\text { Catalytic } \\
\text { oxidation wet } \\
\mathrm{H}_{2} \mathrm{O}_{2}\end{array}$ & $\begin{array}{l}\text { Caudo et al. } \\
(2007)\end{array}$ \\
\hline $\begin{array}{l}\text { Polyphenols olive oil mill } \\
\text { wastewater }\end{array}$ & Cu-based zeolite & $\begin{array}{l}\text { Zeolite } \\
\text { commercial } \\
\text { bentonite }\end{array}$ & $\begin{array}{lr}\text { Catalytic } & \text { wet } \\
\text { oxidation } & \text { with } \\
\mathrm{H}_{2} \mathrm{O}_{2} & \\
\end{array}$ & $\begin{array}{l}\text { Giordano et } \\
\text { al. (2007) }\end{array}$ \\
\hline \multicolumn{5}{|l|}{ Cu-PILC } \\
\hline $\begin{array}{l}\text { Wastewater from agro- } \\
\text { food production }\end{array}$ & $\mathrm{Cu}-\mathrm{PILC}$ & $\begin{array}{l}\text { Commercial } \\
\text { bentonite }\end{array}$ & $\begin{array}{lr}\text { Catalytic } & \text { wet } \\
\text { oxidation } & \text { with } \\
\mathrm{H}_{2} \mathrm{O}_{2} & \\
\end{array}$ & $\begin{array}{l}\text { Caudo et al. } \\
(2008)\end{array}$ \\
\hline
\end{tabular}

\section{Clays characterization:-}

Heterogeneous catalysts prepared by a modified raw-claywith iron oxides, have been used in oxidative reactions of toluene. Fe-ppt and Fe-imp were prepared by precipitation and impregnation of iron oxide, respectively (Figure 2.) (Nogueira et al., 2011). Themeasurementsof specific surface area indicated an increasing of the surface area from 17 $\mathrm{m}^{2} \mathrm{~g}^{-1}$ for raw clay, to $62 \mathrm{~m}^{2} \mathrm{~g}^{-1}$ for Fe-ppt catalyst.However, for Fe-imp sample the particle size distribution was found to be even more uniform than for the raw clay. Also, it is interesting to observe that there are iron phases with high crystallinity in the Fe-ppt compared with the Fe-imp, indicating a higher exposure of iron oxide. 


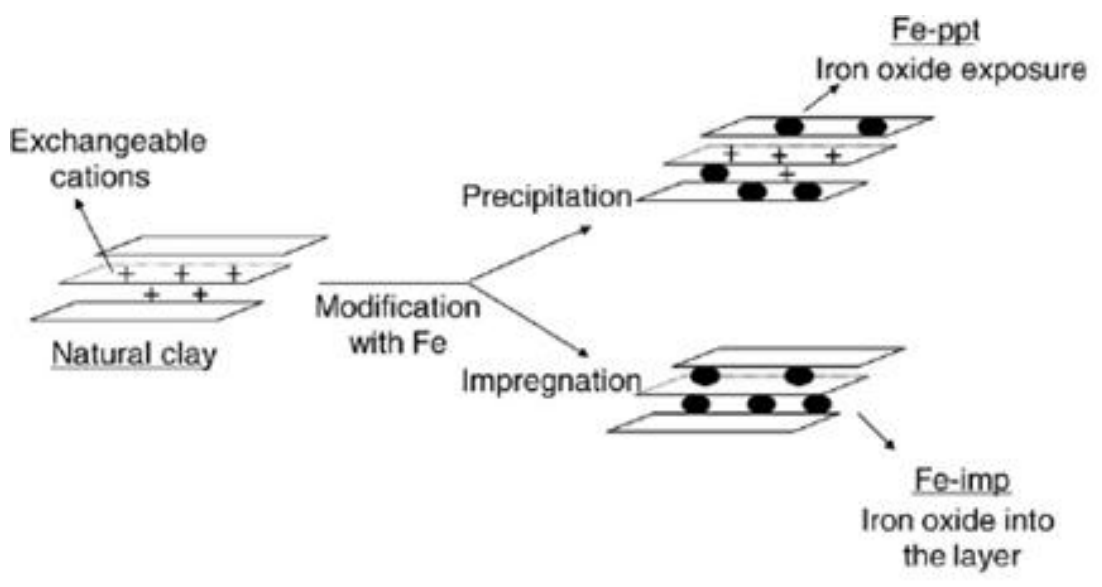

Figure 2:- Preparation scheme of iron oxide con montmorillonite (Nogueira et al., 2011).

Alumina-pillared montmorillonite was used as a support in the oxidation of chlorobenzene over palladium and platinum. The catalysts were prepared by wet impregnation (Aznárez et al., 2015). The selectivity to chlorobenzene was considerably higher over the Pd/Al-PILC catalysts than over their Pt/Al-PILC counterparts, due palladium is known to be a more active chlorination catalyst than platinum.

Due to the increase in the emission of gaseous pollutants into the atmosphere, adsorption and/or retention of gases by clays has also been studied (Volzone, 2007). The presence of the different interlayer cations in smectite, changes the behavior of the clay minerals in aqueous dispersions and also the adsorption of gases. It has been demonstrated that the adsorption of $\mathrm{O}_{2}, \mathrm{~N}_{2}, \mathrm{CO}, \mathrm{CH}_{4}, \mathrm{C}_{2} \mathrm{H}_{2}$ and $\mathrm{CO}_{2}$ gases by different cation exchanged montmorillonites, decrease in the order $\mathrm{H}^{+}>\mathrm{K}^{+}>\mathrm{Ca}^{2+}>\mathrm{Al}^{3+}>\mathrm{Na}^{+}$montmorillonite. The capacity for adsorption of gases by PILCs follows the order: $\mathrm{Al}-\mathrm{PILC} \cong \mathrm{Zr}>\mathrm{Ti}>\mathrm{Cr}$-PILC and the gas adsorption capacity of all these PILCs follow the order $\mathrm{CO}_{2}>\mathrm{CH}_{4}>\mathrm{N}_{2}=\mathrm{O}_{2}$. The modified-Al-PILCs are better solid adsorbents than Al-PILCs for $\mathrm{CO}_{2}, \mathrm{CH}_{4}, \mathrm{~N}_{2}, \mathrm{O}_{2}, \mathrm{C}_{2} \mathrm{H}_{2}$, $\mathrm{CO}$.

\section{Conclusions:-}

Desirable characteristics of a catalyst-support are stability, inertness, reusability, high surface area, porosity and appropriate chemical structure. Among a wide range of support-materials, so far, materials that appear to meet optimally these characteristics optimally are Zeolite and Clays. Supports keep the catalytic phase highly dispersed, thus protecting it from sintering and supported catalyst has shown better catalytic performance for catalytic processes. The type of the modification affects the activity of the supported catalysts because modifications affect substantially the chemical nature of the surface and on the pore texture formation. Results suggest supported catalyst are employed in antimicrobial, medical and environmental applications.

\section{Acknowledgements:-}

Authors want to thank to the National University of Colombia free access to databases.

\section{References:-}

1. Aznárez, a., Delaigle, R., Eloy, P., Gaigneaux, E. M., Korili, S. a., \& Gil, a. (2015). Catalysts based on pillared clays for the oxidation of chlorobenzene. Catalysis Today, 246, 15-27.

2. Cundy, C. S., \& Cox, P. a. (2005). The hydrothermal synthesis of zeolites: Precursors, intermediates and reaction mechanism. Microporous and Mesoporous Materials, 82(1-2), 1-78.

3. Garrido-Ramírez, E. G., Mora, M. L., Marco, J. F., \& Ureta-Zañartu, M. S. (2013). Characterization of nanostructured allophane clays and their use as support of iron species in a heterogeneous electro-Fenton system. Applied Clay Science, 86, 153-161.

4. Garrido-Ramírez, E. G., Theng, B. K. G., \& Mora, M. L. (2010). Clays and oxide minerals as catalysts and nanocatalysts in Fenton-like reactions - A review. Applied Clay Science, 47(3-4), 182-192.

5. Kim, Y. K., Rajesh, K. P., \& Yu, J.-S. (2013). Zeolite materials prepared using silicate waste from template synthesis of ordered mesoporous carbon. Journal of Hazardous Materials, 260, 350-7. 
6. Li, Y., Lu, Y., \& Zhu, X. (2006). Photo-Fenton discoloration of the azo dye X-3B over pillared bentonites containing iron. Journal of Hazardous Materials, 132, 196-201.

7. Martín, J. M. (2001). Síntesis, caracterización y aplicaciones catalíticas de zeolitas básicas. Retrieved from biblioteca.ucm.es/tesis/qui/ucm-t25174.pdf

8. Mirzaei, A. A., Vahid, S., \& Torshizi, H. O. (2013). Effect of support and promoter on the catalytic performance and structural properties of the Fe-Co-Ni catalysts for CO hydrogenation. Journal of Natural Gas Science and Engineering, 15, 106-117.

9. Mousavi, S. F., Jafari, M., Kazemimoghadam, M., \& Mohammadi, T. (2013). Template free crystallization of zeolite Rho via Hydrothermal synthesis: Effects of synthesis time, synthesis temperature, water content and alkalinity. Ceramics International, 39(6), 7149-7158.

10. Musyoka, N. M., Missengue, R., Kusisakana, M., \& Petrik, L. F. (2014). Conversion of South African clays into high quality zeolites. Applied Clay Science, 97-98, 182-186.

11. Musyoka, N. M., Petrik, L. F., Fatoba, O. O., \& Hums, E. (2013). Synthesis of zeolites from coal fly ash using mine waters. Minerals Engineering, 53, 9-15.

12. Nabavi, M. S., Mohammadi, T., \& Kazemimoghadam, M. (2014). Hydrothermal synthesis of hydroxy sodalite zeolite membrane: Separation of H2/CH4. Ceramics International, 40(4), 5889-5896.

13. Nogueira, F. G. E., Lopes, J. H., Silva, A. C., Lago, R. M., Fabris, J. D., \& Oliveira, L. C. a. (2011). Catalysts based on clay and iron oxide for oxidation of toluene. Applied Clay Science, 51(3), 385-389.

14. Park, K. W., Jung, J. H., Seo, H. J., \& Kwon, O. Y. (2009). Mesoporous silica-pillared kenyaite and magadiite as catalytic support for partial oxidation of methane. Microporous and Mesoporous Materials, 121(1-3), 219225.

15. Pérez, A., Montes, M., Molina, R., \& Moreno, S. (2014). Modified clays as catalysts for the catalytic oxidation of ethanol. Applied Clay Science, 95, 18-24.

16. Ramirez, J. H., Costa, C. a., Madeira, L. M., Mata, G., Vicente, M. a., Rojas-Cervantes, M. L., ... MartínAranda, R. M. (2007). Fenton-like oxidation of Orange II solutions using heterogeneous catalysts based on saponite clay. Applied Catalysis B: Environmental, 71, 44-56.

17. Rios, C. ., Williams, C. ., \& Castellanos, O. . (2006). Síntesis y caracterización de zeolitas a partir de la activación alcalina de caolinita y subproductos industriales (cenizas volantes y clinker natural) en soluciones alcalinas. BISTUA, 4(2), 60-71.

18. Sanabria, N., Álvarez, A., Molina, R., \& Moreno, S. (2008). Synthesis of pillared bentonite starting from the Al-Fe polymeric precursor in solid state, and its catalytic evaluation in the phenol oxidation reaction. Catalysis Today, 133-135, 530-533.

19. Volzone, C. (2007). Retention of pollutant gases: Comparison between clay minerals and their modified products. Applied Clay Science, 36, 191-196.

20. Zaarour, M., Dong, B., Naydenova, I., Retoux, R., \& Mintova, S. (2014). Progress in zeolite synthesis promotes advanced applications. Microporous and Mesoporous Materials, 189, 11-21.

21. Zhang, X., Tang, D., \& Jiang, G. (2013). Synthesis of zeolite NaA at room temperature: The effect of synthesis parameters on crystal size and its size distribution. Advanced Powder Technology, 24(3), 689-696.

22. Zhang, X., Tang, D., Zhang, M., \& Yang, R. (2013). Synthesis of NaX zeolite: Influence of crystallization time, temperature and batch molar ratio $\mathrm{SiO} 2 / \mathrm{Al} 2 \mathrm{O} 3$ on the particulate properties of zeolite crystals. Powder Technology, 235, 322-328.

23. Zhou, C. H., \& Keeling, J. (2013). Fundamental and applied research on clay minerals: From climate and environment to nanotechnology. Applied Clay Science, 74, 3-9. 